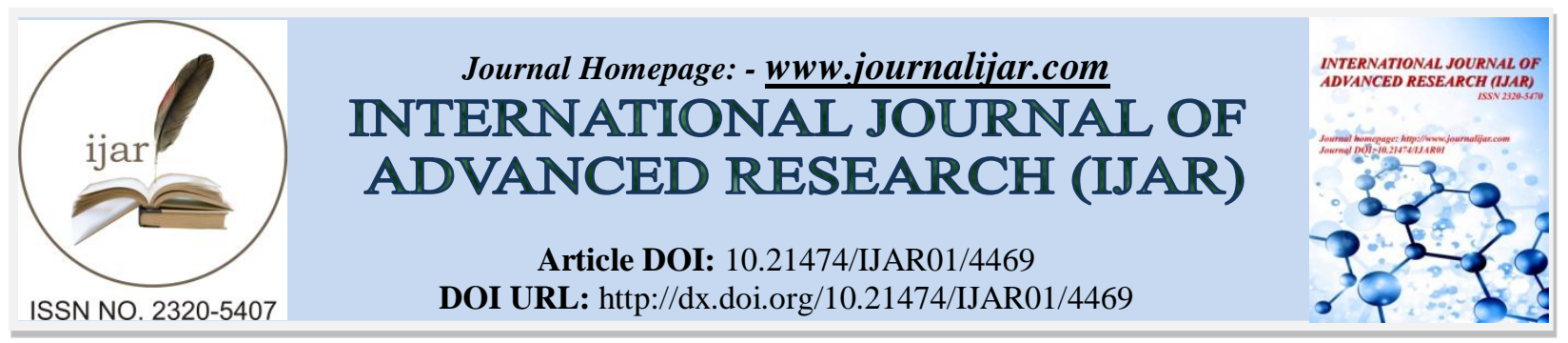

RESEARCH ARTICLE

\title{
EFFECT OF FLOODING ON STOMATAL DENSITY AND STOMATAL LENGTH IN SIX SUGARCANE GENOTYPES.
}

${ }^{*}$ PhD Sergio Rodríguez Rodríguez ${ }^{1}$, PhD Eduardo Ortega² and PhD Juan Jose Silva Pupo ${ }^{3}$.

1. Centro de Estudios de Biotecnología Vegetal. Facultad de Ciencias Agrícolas. Universidad de Granma. Carretera a Manzanillo, km 17. Bayamo CP 85 100. Granma. Cuba.

2. Laboratorio de Fisiología Vegetal. Facultad de Biología. Universidad de la Habana. Cuba.

3. Centro de Estudios de Biotecnología Vegetal. Facultad de Ciencias Agrícolas. Universidad de Granma. Carretera a Manzanillo, km 17. Bayamo CP 85 100. Granma. Cuba

\section{Manuscript Info}

Manuscript History

Received: 13 April 2017

Final Accepted: 15 May 2017

Published: June 2017

Key words:-

sugar cane, flooding, stomata

\section{Abstract}

When abundant precipitations are associated to physical edaphic problems then excesses of water may appear in soils of agricultural interest, affecting dissimilarly to the morfophysiology of the crop plants. The experiment was a split plot design at random in complete blocks with five repetitions in a Typic Hapluster soil. The presence or absence of the soil flooding was considered like plots and the genotypes like sub-plots. Stomatal density and stomatal length were measured in 10-mo old sugar cane plants in two crop cycles, plant cane and first ratoon. The stress intensity was determined. It was proven that the stress intensity inverted increased the stomatal density at a $9.0 \%$ in plant cane and first ratoon, while the stomatal length in excess of water in soil was reduced at $12.0 \%$ for both crop cycles, with important differences among the studied genotypes. Inverse correlations were detected between stomatal density and stomatal length. It concluded that the oxygen deficiency in flooding soil induces morphologic changes in the stomatal density and length with wide differentiation among genotypes in plant cane and first ratoon crops cycles.

Copy Right, IJAR, 2017,. All rights reserved.

\section{Introduction:-}

The flooding of the soil is a worldwide problem; it is considered that the $6.0 \%$ of terrestrial surface is occupied by flooded areas or prone to a temporary flooding (Maltby, 1991). Flooding may be due to excessive rains, drainage deficiency, filtration from watering channels, rivers flooding, etc. (Magalhães et al., 2000). In soils with these characteristics the diffusion of the gases to the atmosphere is seriously affected (Armstrong et al., 1994). On the other hand, the aerobic breathing of plants and microorganisms reduce the oxygen levels quickly in the soil solution, favoring the formation of a hypoxic and anoxic environment (Gomes de Moraes et al., 2001), that ends with the disappearance of the sensitive vegetation (Crawford and Braendle, 1996). Some plant species are able to survive to flooding because they have developed, along the evolution's long process, morphological, metabolic and anatomical mechanisms of adaptations (Vartapetian and Jackson, 1997; Jackson and Colmer, 2005).

Corresponding Author:- Sergio Rodríguez Rodríguez.

Address:- Centro de Estudios de Biotecnología Vegetal. Facultad de Ciencias Agrícolas. Universidad de 
Plant anatomical structures with important physiological functions are stomata, which respond quickly to the fluctuations produced in the environment. Variations in the stomata density, size and in the opening and closing are due to environmental changes.

The stomata are plant structures through which the necessary $\mathrm{CO}_{2}$ penetrates for the photosynthesis process, they also facilitate the transpiration, which generates a tension that is transmitted towards the xylem, creating a suction that facilitates the entrance of water and mineral salts to the plant (Cháves, 1991). A very usual form of measuring the distribution of the stomata in the leaf surfaces is through its density or frequency (Croxdale, 2000). This frequency or density is under genetic control, but can be modified by environmental changes (Kouwenberg et al., 2004).

The aim of this work was to evaluate if the soil flooding induces morphological changes in the stomatal density and length in the sugarcane varieties C86-456, C90-469, C86-12, C87-51, C1051-73 and C120-78 in plant cane and first ratoon cycles

\section{Material and methods:-}

The experiment was developed in the Sugar Enterprise "Grito de Yara", located in Río Cauto municipality, Granma County, Cuba. The region is called The Valley of the Cauto River. The soil is a Typic Haplustert according with the Soil Taxonomy (Soil Survey Staff, 2003). The experiment was carried out following the Norms and Procedures of the Program of Genetic Improvement of the Sugarcane in Cuba, of the National Institute of Sugarcane Research (INICA, 1987, 2002). It was an experimental split plot design at random in complete blocks of $48 \mathrm{~m}^{2}$ (4 furrows of $7.5 \mathrm{~m}$ length and $1.60 \mathrm{~m}$ of distance among them) with five repetitions. Each plot was separated $50 \mathrm{~m}$ from the others to avoid lateral water infiltrations and in this interval 10 gutters of $0.50 \mathrm{~m}$ depth separated $1 \mathrm{~m}$, were built with the same purpose.

In the plot without flooding, all the measures cropping farm were adopted, so that the factor flooding was null. The plot with flooding was prepared by building a dike $50 \mathrm{~cm}$ high bordering the plot, to avoid the free movement of the water, and adding a plate of water of $40 \mathrm{~cm}$ at the $120 \mathrm{~d}$ of planting the plant cane and starting from its harvest for the first ratoon, every $10 \mathrm{~d}, 3 \mathrm{~d}$ of flooding, until the $300 \mathrm{~d}$ or $10 \mathrm{mo}$, except when the precipitations raised up the plate of water until $40 \mathrm{~cm}$. In the first $120 \mathrm{~d}$ [the most susceptible stage to flooding (Van Dillewijn, 1951)], both plots were surface irrigated with a partial net norm of $237 \mathrm{~m}^{3} \mathrm{ha}^{-1}$, every $12 \mathrm{~d}$, in order to guarantee homogeneity in the harvest and the final quantity of stalks. This irrigation was applied in the non flooding experiment until the 10 mo.

Sugarcane genotypes used (parentals are among parenthesis) were: C86-456 (PR980 x Ja60-5), C90-469 (Ja60-5 x C87-51), C86-12 (Unknown), C87-51 (Co281 x POJ2878), C1051-73 (B42231 x C431-62) and C120-78 (Co421 x C87-51) (Bernal et al., 1997; Jorge et al., 2004). Stalks coming from the Seed Basic Bank of the Granma province were selected as material of plantation. This material had been previously thermal and chemically treated to prevent potential diseases. Two stalks of three buds of each genotype were planted in the furrows, in order to guarantee a density plant population of $98.0 \%$ in the experiment. Plots were planted in January 2002.

The farming practices carried out in the plots were: irrigation as previously mentioned, six manual cleanings, and fertilization following the Recommendations Service of Fertilizers and Amendments (SERFE) of the Cuban National Institute of Sugarcane Research. The evaluated crop cycles were the plant cane crop and the first ratoon crop.

\section{Determining the stomatal density and stomatal length:-}

It was carried out at 10 mo of starting both experiments and crop cycles. A representative graft of each variety and repetitions were taken at 9:00 am. The leaf +3 was selected (a leaf already formed), according to the classification of Kuijper (1915), collected from primary stalks. Thirty clean leaves were chosen and without affectations of diseases or pests (six varieties and five repetitions), taken to the laboratory and kept at $4.0^{\circ} \mathrm{C}$.

Stomatal density (stomata $\mathrm{mm}^{-2}$ ) was measured: in the abaxial leaf surface and in their half section (measured with a metric tape) or central of the collected leaves it was applied translucent polish. After 15 min, polish was removed to evaluate the stomata density, according to Ortega and Ródes (1990). The preparations were placed in slides and 50 fields of each variety were read with a microscope, using a micrometer. Special care was taken to count the fields 
from the area that is adjacent with the central part of the leaf vein towards the border of the leaf blade, to achieve bigger representativeness and uniformity in the sampling. The reading was made at 40x, always the stomatal number per field of the surface abaxial of the leaf, considering that this side of the leaf in sugarcane, has approximately double stomata that the adaxial one (Van Dillewjin, 1951).

To measure the stress tolerance the stress intensity (SI) or relative loss of the selected variables stomatal density and stomatal length) was calculated following Fisher and Maurer (1978) method. When the stress increased the studied variable above the non-stressing condition, the calculations were inverted (inverted stress intensity (ISI), and was interpreted as the increment relative to the selected variable.

\section{Statistical analyses:-}

The statistical analysis was done by using the Infostat software (Di Rienzo et al., 2013). The entire primary database was verified in order to fulfill the premises of the analysis of variance: the adjustment to the normal distribution, through the Kolmogorov-Smirnov test and the homogeneity of the variances, applying the Bartlett test ( $\mathrm{p}<0.05)$. The total variability in the experimental sample was analysed through a split plot design at random in complete blocks. An analysis of variance was carried out, considering the conditions of soil humidity like plots (A) and the genotypes like sub plots (B), to detect the existence of interactions between these two factors.

The analysis of variance for the pattern of fixed effects was used for both crop cycles, in the two variables stomatal density and stomatal length. Tukey's range test was used, for $\alpha=0.05$. The interaction average was shown through independent factors, with their respective standard errors (SE) which coincide with their corresponding variables. To know the correlation level between the stomatal density and stomatal length, the Pearson Coefficient was applied. The $\mathrm{p}$ values were adjusted by the Bonferroni test (Rice, 1989).

The $t$ student test was used to know if the affectations causes by the flooding stress of the soil were significant, when comparing each genotype individually under the two present conditions of soil humidity for the two variables. The significance level is shown among the mean of each genotype in each condition, being the starting point for the estimation of the SI or relative's loss of the variable in study.

The Principal Coordinates Analysis was used as method multivariate of multidimensional scaling combined with Minimum Spanning Trees (Gower and Ross, 1969), to demonstrate the degree of likeness between two varieties related to the stomatal density and length in the multivariate space.

\section{Results:-}

\section{Stomatal density and length:-}

With respect to the stomatal density, there were significant differences in plant cane and first ratoon in the interaction among the factors. Fig. 1 shows that genotypes C86-456, C90-469, C87-51 and C86-12 presented the highest stomatal density to flooding in the soil, on the contrary to what was observed in varieties C86-456, C90-469, C87-51, C1051-73 and C120-78, with the smallest values of stomatal density in absence of flooding of water in the soil. This behavior was observed both in plant cane and in the first ratoon crops. The increase caused by flooding in the stomatal density, based on the SI Inverted, was significant in both crop cycles and in all the genotypes, with the highest increments observed in the varieties C86-456, C90-469 and C86-12. In the case of the stomatal length (Fig. 2), the significance levels corresponded to the independent factors. The factor A or flooding of the soil in the two crop cycles diminished significantly the stomatal length, but the varieties or factor B behaved inversely to what was observed in the stomatal density, i.e. the varieties that showed the highest values in stomatal density, presented the shortest stomata, this was statistically demonstrated in Table 1, where inverse correlations highly significant were observed in both crop cycles, both in non flooding and flooding conditions. The correlation coefficients were higher between these two variables under flooding conditions, specifically in the genotypes C86-456, C90-469 and C86-12, that evidenced the alteration of the magnitude of these associations when the six sugarcane varieties studied were developed in soils with anaerobic processes. 

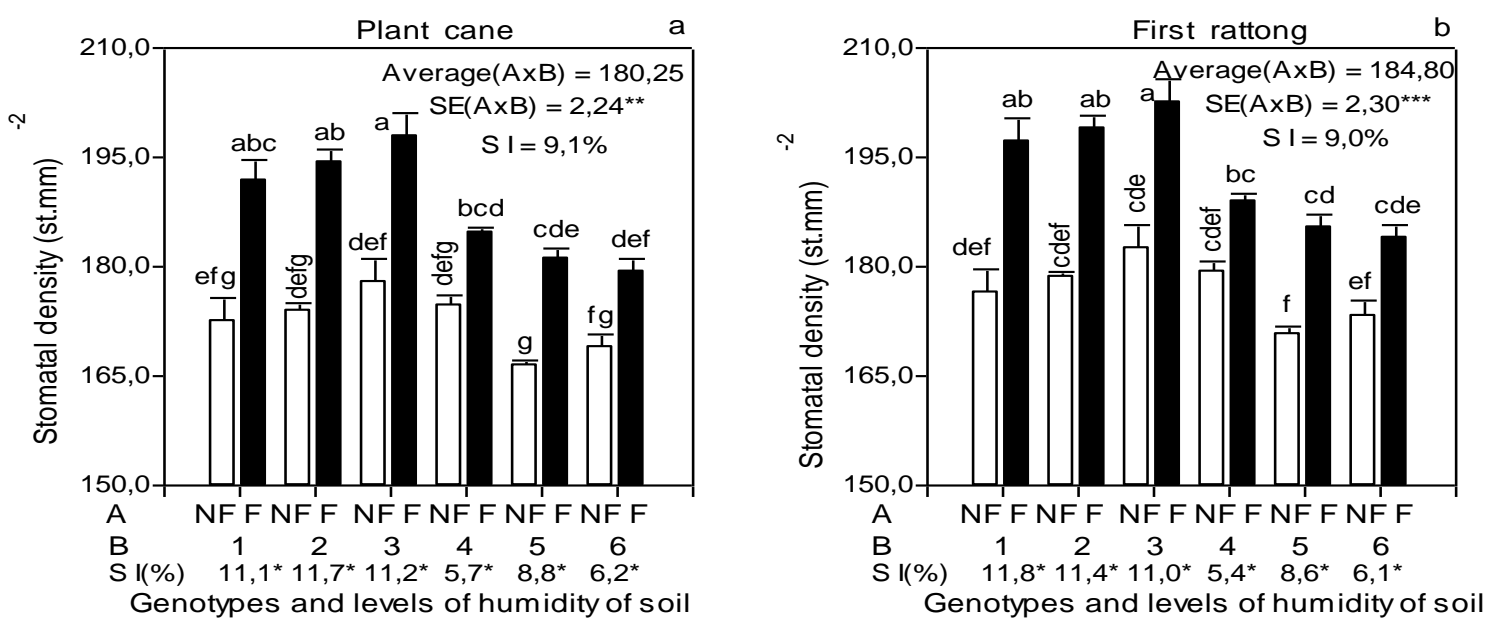

Figure 1:- Stomatal density for independent crop cycles with statistical interaction among the factors, (a) plant cane, (b) first ratoon. Factor A, levels of humidity of the soil (NF, non flooded and F, flooded). Factor B, genotypes (1: C86-456; 2: C90-469; 3: C86-12(3); 4: C87-51; 5: C1051-73; 6: C120-78. It is included for each genotype the stress intensity (SI) or relative loss of the stomata density and their significance.

Note: Different letters indicate significant differences for $\mathrm{p}<0.05$, using Tukey.

$*, * *$ and $* * *$, indicate significant differences for $\mathrm{p}<0.05,0.01$ and 0.001 respectively, using student $\mathrm{t}$ test.
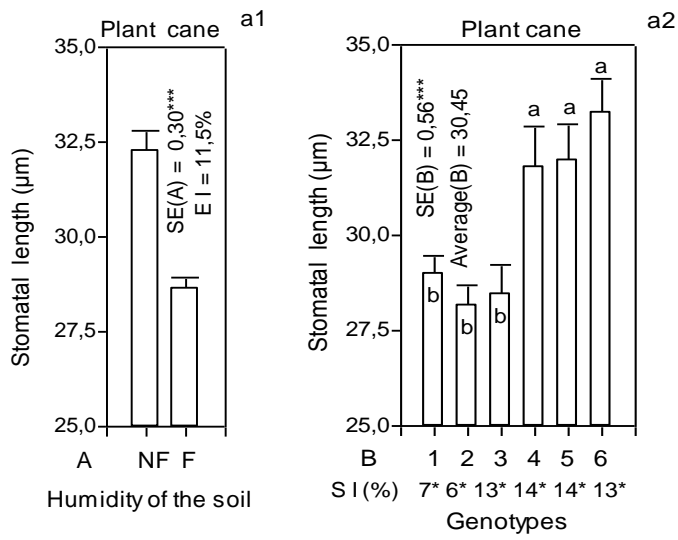

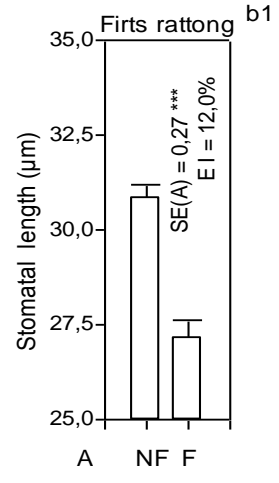

Humidity of the soil

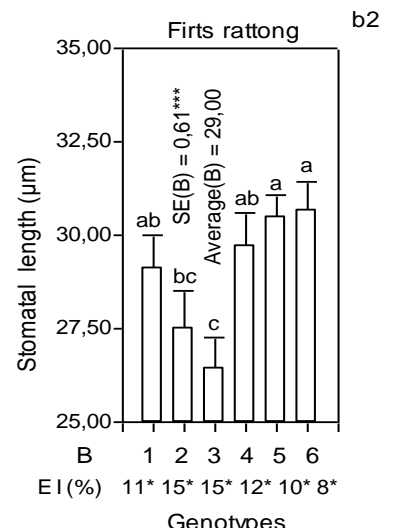

Genotypes

Figure 2:- Stomatal length for independent crop cycles, with statistical interaction among the factors: (a1 and a2) plant cane (b1 and b2) first ratoon. Factor A, levels of humidity of the soil (NF, non flooded and F, flooded). Factor B, genotypes (1: C86-456; 2: C90-469; 3: C86-12(3); 4: C87-51; 5: C1051-73; 6: C120-78. For each genotype is included the stress intensity (IE) or relative loss of the stomata length and their significance.

Note: Different letters indicate significant differences for $\mathrm{p}<0.05$, using Tukey test $*, * *$ and $* * *$, indicate significant differences for $\mathrm{p}<0.05,0.01$ and 0.001 respectively, using student $\mathrm{t}$ test.

Table 1:- Partial correlations between the stomata density and stomata length in the six sugarcanes genotypes, in plant cane and first ratoon stages, under flooding (F) and non flooding (NF) soil conditions.

\begin{tabular}{|c|c|c|c|c|}
\hline \multirow{3}{*}{ Genotypes } & \multicolumn{4}{|c|}{ Correlation coefficient $(\mathrm{r})$} \\
\hline & \multicolumn{2}{|c|}{ Plant cane } & \multicolumn{2}{|c|}{ First ratoon } \\
\hline & NF & $\mathrm{F}$ & $\mathrm{NF}$ & $\mathrm{F}$ \\
\hline C86-12 & $-0.66 *$ & $-0.92 * *$ & $-0.57 *$ & $-0.95 * *$ \\
\hline C86-456 & $-0.62 *$ & $-0.95 * *$ & $-0.62 *$ & $-0.96 * *$ \\
\hline C90-317 & $-0.72 *$ & $-0.95 * *$ & $-0.66^{*}$ & $-0.92 * *$ \\
\hline C87-51 & $-0.69 *$ & $-0.87 * *$ & $-0.66^{*}$ & $-0.86 * *$ \\
\hline C1051-73 & $-0.70 *$ & $-0.86 * *$ & $-0.67 *$ & $-0.88 * *$ \\
\hline C120-78 & $-0.60 *$ & $-0.85 * *$ & $-0.62 *$ & $-0.86 * *$ \\
\hline
\end{tabular}


In the Principal Coordinates Analysis (Fig. 3), the percentage of the total variability explained by the two coordinates was in the plant cane cycle of $95.9 \%$ and of $99.3 \%$ in the first ratoon respectively, constituting a distinctive sign of the high correlation existed among variables.
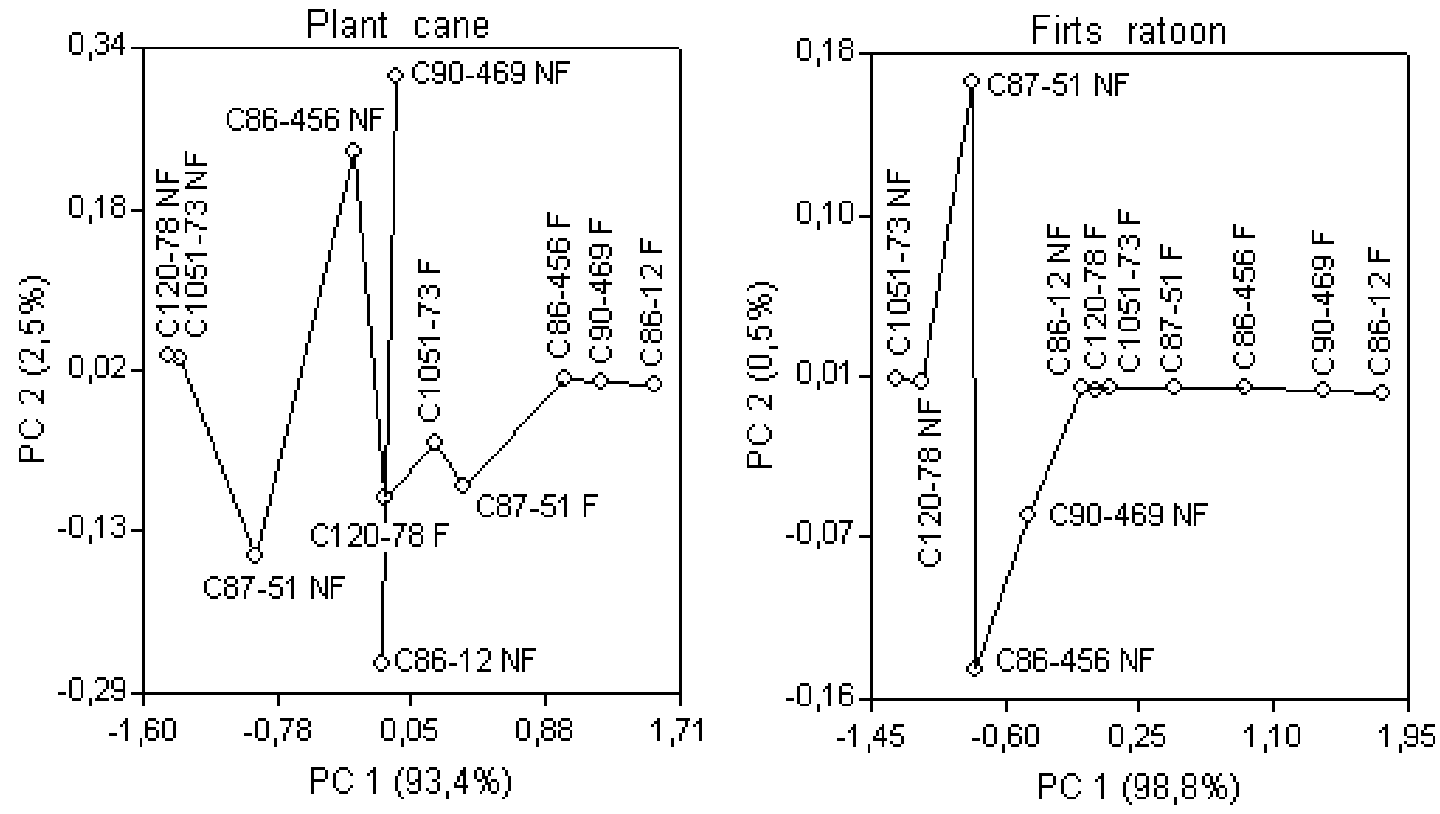

Figure 3:- Minimun Spanning Tree in the Principal Coordinates Analysis of the six sugarcane varieties related to stomatal density and length in plant cane and first ratoon crop cycle in flooding (F) and non flooding (NF) conditions.

Following the Minimum Spanning Trees the C120-78 and C1051-73 varieties are very similar related to stomatal density and length in non flooding conditions of the soil, with certain likeness with C87-51, distanced in great extent of the group of varieties C86-456, C90-469 and C86-12. The three first varieties maintained that similarity in flooding conditions; but visibly distanced due to the variations induced by this stress in the density and the length of the stomas.

Contrary to the plant cane, the Minimum Spanning Trees of the first ratoon showed absence of ramifications, indicating that in this crop cycle there is great similarity among the varieties regarding to the density and length of the stomas. The similarity among the varieties C120-78, C1051-73 and C87-51 on one hand and between C86-456, C90-469 and C86-12 for the other one, were coincident with the plant cane cycle and in the two conditions of soil humidity. The biggest difference was found between C86-456 and C87-51 in both crop cycles in non flooding conditions. A case that can be considered abnormal was the high likeness found in the density and length stomata of the variety C86-12 in non flooding conditions and the C120-78 in flooding conditions, tendency also observed in the plant cane cycle, although less accented.

\section{Discussion:-}

Differences in stomatal density were found in six sugarcane varieties which in many cases may be due to genetic differences. Although, in the case of the six genotypes used in this work, they have become related process very similar to the original genetic trait. This is due to, the nobilization process that occurs since many years in Cuba, due to the programs of genetic improvement of the sugarcane developer.

Campa (1986), when studying the stomatal density, comparing sheets leaf of the collected leaf +1 of primary stalks of Erianthus elegans (?); Saccharum officinarum L. (original Lahaima form); S. spontaneum L. (original Mandalay form); S. robustum Brandes et Jesw (original NG51-55 form) and S. barberi Jesw (original Chunnee form), found significant differences among the different genus in both epidermis, standing out for the abaxial leaf surface the genus $S$. officinarum with the highest values (245.0 stomata $\mathrm{mm}^{-2}$ ) and $S$. spontaneum with the lowest values (126.0 stomata $\mathrm{mm}^{-2}$ ); the rest of the genus presented an intermediate behavior. 
In the present study, the values of stomatal density were grouped near and below those obtained by Campa (1986), for $S$. officinarum, although it should be considered that for this research leaf +3 was used. The similarity between these results is a consequence of the small genetic base which is used in the hybridization campaigns, that is considered to be one of the biggest limitations in the sugarcane improvement in Cuba, due to the reduced number of the original genus and shape that were used on the nobilization program as progenitors in the selected programs of commercial sugarcane varieties (Cornide and Gálvez, 1999; Cornide, 2001).

According to the research made with crops under this stress type (Magalhães, 2001), in general is concluded that the flooding stress decrease the stomatal conductance of the plants, in those compared with the developed in a nonstress environment. Specifically for the sugarcane, Humbert (1965) pointed out that under flood conditions the transpiration decreases considerably. Glaz et al. (2004) demonstrated that the flooding in sugarcane reduced the transpiration and the stomatal conductance. Medlyn (2001) indicated that those variations in the stomatal conductance are owed in great measure to variations in their stomatal density. It is well known that the pattern response of the stomatal density in the leaf surface of the plants is under the genetic control (Kouwenberg et al., 2004). However, it can be modified by environmental variables such as the concentration of carbon dioxide in the atmosphere (Croxdale, 2000; Glover, 2000; Kouwenberg et al., 2003; Wagner et al., 2005), or by differences in the luminous intensity or the readiness of water (Royer, 2001).

The previous considerations in genotypes of sugarcane with bigger stomatal density and smaller stomatas, are under better conditions in order to adapt their physiology in stress situations, that also affect the hydric balance of the plant, as the flooding case, that induces the stomata to close. Varieties with these characteristics are able to close their stomatas faster and they decrease the loss of water for transpiration, as a mechanism to adapt the excess water in the soil.

The results obtained in this research are found in the ranges that Hetherington and Woodward (2003), settled down for the length of the stomata among $10-80 \mu \mathrm{m}$ and densities that are in the range of 5-1.000 $\mathrm{mm}^{-2}$, according with the species and the environmental conditions, but despite of this big variation, a strong dependent relationship has been found between the stomatal density and the size of the stomata in different plant species.

The quick response from the stomata to the environmental changes in stress seems to be the distinctive feature, so that, the plant maintains the movement of the water from the soil towards the leaf (Raven, 2002). Some studies carried out by Aasamaa et al. (2001), showed that the stoma size has a big importance in the response, when inverse correlations are found between conditions of drought and the stomatal length.

In the Poaceas, where the sugarcane is included the opening and closing mechanism of the stomata is very sensitive, which makes them more efficient than other species to the environmental changes (Grantz and Assmann, 1991). On the other hand, it allows high photosynthetic rates with the stomata closed due to the high match for the $\mathrm{CO}_{2}$ of the enzyme phosphoenol piruvate carboxilase (Tadeo, 2000). Small stomata, can open up and close more quickly and are associate generally to high stomatal density (Aasamaa et al., 2001), they provide to the plant the capacity of increasing the stomatal conductance of the leaf quickly, maximizing the interior diffusion of the $\mathrm{CO}_{2}$ during favorable conditions for the photosynthesis.

The $\mathrm{CO}_{2}$ penetrates for the stomata with high speed, the cause resides in the peculiarities of the process of diffusion of gases through small holes. By virtue of that the diffusion through small holes is proportional to the diameter of these, whenever it diminishes the diameter, the diffusion speed increases for surface unit (Rubin, 1984). In general, the stress conditions produce increment in the stomatal density (Heckenberger et al., 1998), however, other researches did not find answers (Centritto et al., 1999).

The increment of the stomatal density in flooding soil is related with under these conditions the leaves of the sugarcane achieved smaller foliar expansion, tendency also found in the tobacco (Nicotiana tabacum L) by Fonseca (2006), making vary the solar radiation intensity. It has been demonstrated that inverse correlation exists between the stomatal density and the leaf area, due to the stomata spacing and not to the different proportion in the development of these structures (Tichá, 1991). 
The plants can communicate from cell to cell or through signs at long distance among the upper and underground parts (Lake et al., 2002; Dat et al., 2004). A response to the roots flood, the stomata closes are closed $2 \mathrm{~h}$ after the flooding being, to avoid the dehydration, under the same premises of the epinasty (Schoeder et al., 2001).

One of the first symptoms that shows the flooded plants is the closing of the stomata (Kozlowski, 1997), inducing a significant reduction of the stomatal conductance that shows a tendency to be accentuated with the duration of the flooding (De Carvalho and Ishida, 2002). Although aperture is influence for guard and epidermal cell turgor pressure (Franks et al., 1998; Buckley, 2005).

The stomata's response under low restrictive oxygen in the soil, is a field of contradictory evidence, based on the absence from a coherent state to the quick closing of these when the plant undergoes this stress and the permanent action of this closing, a time after having disappeared the stress condition. Researches that have demonstrated the influence of the abscisscic acid (Jackson et al., 2003), in the closing of the stomata. Dell'Amico et al (2001), demonstrated in tomato plants (Lycopersicum esculentum $\mathrm{M}$ ), in flooding conditions that water potential is a physical type sign that induced the closing of the stomata and once this water potential is recovered, the stomata stayed closed a time later, a result of the permanent action of chemical signs. In sugarcane, the researches indicate that chemical sings that go from the roots are responsible for the control of the closing of the stomata (InmanBamber and Smith, 2005).

The dissimilarity or found differences with the Minimum Spanning Trees captured between two in the biggest or smaller distance varieties are a sample of the variability that induce the genotypes influenced by the variations that caused the changing environment, while the similarity could have be influenced by the degree of consanguinity of these varieties. From the most remote times, the plants have not been able to avoid the fluctuations that the environment, guiding the phenotypic plasticity of several of their characters in correspondence with these variations (Puijalon and Bornette, 2006; Adams, 2007). Plasticity is the property that has a genotype of producing different phenotypes in dependence of the environment (Schmalhausen, 1949), aspect very related to the morphological changes (de Kroon et al., 2005; Wolfe and Mazer, 2005).

The water is among the main factors of the environment that induces plasticity in correlated simple characters (Barrilleaux and Grace, 2000), to be a crucial abiotic factor and highly variable for all the alive organisms. For the plants the deficit or the excess of this are a characteristic example of these ends (Galen, 2000; Zhang et al., 2000), constituting the clonal variation an important factor related to the tolerance to the stress that influences in the plants populational structure (Howard and Rafferty, 2006).

Therefore, it is of great importance to know the morphological changes that the plants show when varying the environmental conditions, especially, the structure of the stomas, based on that reached by Zarinkamar (2007) about that the stomatal characteristics area a valuable research resource, allowing the identification of basic stomatal types in plants and the facilitation of their taxonomic classification to monitor and evaluate environmental changes. Computerized studies have shown that, the variation in the stoma structure change the gases interchange in plants (Roth, 2007).

Pyakurel and Wang (2014), showed that the populations with larger leaf area and specific leaf area had higher hair density but low stomatal density. These leaf characteristics provided a structural basis in reducing water loss through leaves and increasing water use efficiency. A trade-off between stomatal area and density resulted in this study might be a strategy of the birch to balance stomatal conductance in decreased precipitation. Leaf morphological and stomatal studies are valuable for identifying ecologically important traits that can then be further analyzed in other experiments (Lande. and Arnold, 1983; Wade and Kalisz, 1990).

\section{Conclusions:-}

In water relations between the soil and the sugar cane varieties studied, oxygen deficiency periods, due to excess water in the soil triggered adaptive responses in the leaves that make increases on the stomatal density and decrease the stomatal length, which makes more responsive opening and closing to environmental changes to reduce losses by transpiration, but limited the entry of $\mathrm{CO} 2(\mathrm{~g})$, indispensable for photosynthetic reactions at the same time. There is a clear distinction between the studied varieties related with these two variables evaluated, which open the possibility of the existence of interspecific phenotypic variation derived from changes and morphological adaptations that the sugarcane genotypes has been submitted through the different periods of evolution and in 
different weather conditions especially to different levels of moisture from the soil, which can alter the aeration of the soil, affecting the concentration of oxygen, essential to the function of breathing. This interspecific phenotypic variation should be compared with genetics studies as possible morphological indicator in the search and selection of tolerant sugarcane genotypes to soil flooding, considering in Cuba the $40.3 \%$ of cultivated lands is located in poorly drained soils, with tendency to increase, compounded by the effects of current climate change, which in this region of Cuba are becoming with more frequency in extreme climatic events such as droughts and floods. The Valley of the Cauto River, in the Granma province, Cuba, is an area with edaphic and climate favourable conditions so that in certain periods of the year the soils increase the degree of saturation soil water. This valley represents 36.0 $\%$ of the river basin and $31.0 \%$ of its soils is of the type Vertisol. The principal crop is the sugarcane in the region and in the country.

\section{References:-}

1. Aasamaa, K., Sober A., Rahi M. (2001). Leaf stomatical characteristics associated with shoot hydraulic conductance, stomatal conductance and stomatal sensitivity to changes of leaf water status in temperature deciduous trees. Aust J Plant Physiol 28,765-774.

2. Adams, K. (2007). Evolution of duplicate gene expression in polyploid and hybrid plants. Journal of Heredity 61, 1125-1132.

3. Armstrong, W., Rändle R.B., Jackson M.B. (1994). Mechanisms of flood tolerance in plants. Acta Botánica Neerlandica 43,51-58.

4. Barrilleaux, T.C., Grace J.B. (2000). Growth and invasive potential of Sapium sebiferum (Europhorbiaceae) within the coastal prairie region: the effects of soil and regime. Am J Bot 87, 1099-1106.

5. Bernal, N., Morales F., Gálvez G., Jorge I. (1997). Variedades de caña de azúcar. Uso y manejo. Instituto Nacional de Investigaciones de la Caña de Azúcar. IMAGO. La Habana. Cuba. 99 pp. [In Spanish].

6. Buckley, T.N. (2005). The control of stoma by water balance. New Phytology 168, 275-292.

7. Campa, V., Z. (1986). Parámetros epidérmicos y resistencia a la sequía en caña de azúcar. Diploma's thesis. Laboratorio de Fisiología Vegetal. Facultad de Biología. Universidad de la Habana. Cuba. 15pp. [In Spanish].

8. Centrito, M., Maonani F., Lee H.S.J., Jarvis P.G. (1999). Interactive effects of elevated $\mathrm{CO}_{2}$ and drought on cherry (Prunus avium) seedlings. II. Photosynthetic capacity and water relations. New Phytologist 141, 141153.

9. Cháves, M.M., (1991). Effects of water deficits on carbon assimilation. J Exp Bot 42, 1-16.

10. Cornide, M.T., Gálvez G. (1999). Los marcadores moleculares y el programa de mejoramiento de la caña de azúcar. In: Biodiversidad (Arencibia A., Cornide M., ed). Ed Elfos Scientiae, La Habana, Cuba. pp. 45-62. [In Spanish].

11. Cornide, M.T. (2001). La genética vegetal, el mejoramiento y la sociedad. Cultivos Tropicales 22, 73-82.

12. Crawford, R.M., Braendle R. (1996). Oxygen deprivation stress in a changing environment. J Exp Bot 295, 145159.

13. Croxdale, J.L. (2000). Stomatal patterning in angiosperms. Am J Bot 87, 1069-1080.

14. Dat, J.F., Capelli N., Folger H., Bourgeade P., Badot P.M. (2004). Sensing and signaling during plant flooding. Plant Physiol Biochem 42, 273-282.

15. De Carvalho C.J.R., Ishida F.Y. (2002). Responses of young pijuayo plants (Bactris gasipaes Kunth) to flooding. Pesqu Agropec Bras 37, 1231-1237.

16. De Kroon H., Huber H., Stuefer J., Van Groenendael J. (2005). A modular concept of phenotypic plasticity in plants. New Phytologist 166, 73-82.

17. Dell'amico J., Torrecillas A., Rodriguez P., Morales D., Sánches-Blanco M.J. (2001). Differences in the effects of flooding the soil early and late in the photoperiod on the water relations of pot-grown tomato plants. Plant Sci 3, 481-487.

18. Di Rienzo, J.A., Casanoves, F., Balzarini, M.G., González, L., Tablada, M., Robledo, C.W. InfoStat. (2013), Grupo InfoStat, Facultad de Ciencias Agropecuarias, Universidad Nacional de Córdoba, Argentina. URL http://www.infostat.com.

19. Edwards D., Kerps H., Hass H. (1998). Stomata in early land plants: an anatomical and ecophysiological approach. J Exp Bot 49, 255-278.

20. Franks P.J, Cowan IR, Farquhar GD. (1998). A study of stomatal mechanics using the cell pressure probe. Plant, Cell and Envir. 21, 94-100.

21. Fisher R.A., Maurer R. (1978). Drought resistance in spring wheat cultivars. I. Grain yield responses. Aust J Agr Res 29, 897-917. 
22. Fonseca I. (2006). Efecto ecofisiológico del tipo de cobertor sobre algunos indicadores anatómicos fisiológicos y su relación con la agroproductividad en plantaciones de tabaco (Nicotiana tabacum L). Master's thesis. Universidad de Granma - I. I. Jorge Dimitrov. 72 pp. [In Spanish].

23. Galen C. (2000). High and dry: drought stress, sex - allocation trade - offs, and selection on flower size in the alpine wildflower Polemonium viscosum (Polemoniaceae). American Naturalist 156, 72-83.

24. Glaz B., Morris D.R., Daroub S.H. (2004). Sugarcane photosynthesis, transpiration, and stomatal conductance due to flooding and water table. Crop Sci 44, 1633-1641.

25. Glover B.J. (2000). Differentiation in plant epidermal cells. J Exp Bot 51, 497-505.

26. Gomes De Moraes M., Donizeti J.A., Mota De Oliveira L.E., Vitorino P.F., Murad M.M. (2001). Caractericāo do crescimento e da atividae das desidrogenases alcohólica e ática em seis espécies herbáceas sob condicōes de hipoxia. Ciencia Agrotecnica 25, 86-95. [In Portughese].

27. Gower J.C. and Ross P.G.N. (1969). Minimun spanning tress and single cluster analysis. Applied Statistics 18, 54-64.

28. Grantz D.R., Assmann H. (1991). Physiological aspects about the stomatal conductance. Plant Physiol 3, 123130.

29. Heckenberger U., Roggatz U., Schurr U. (1998). Effect of drought stress on the cytological status in Ricinus communis. J Exp Bot 49, 181-189.

30. Hetherington A.M., Woodward F.I. (2003). The role of stomata in sensing and driving environmental change. Nature 424, 901-908.

31. Howard R., Rafferty P. (2006). Clonal variation in response to salinity and flooding stress in four marsh macrophytes of the northern gulf of Mexico, USA. Environ and Experim Bot 56, 301-313.

32. Humbert R.P. (1965). El cultivo de la caña de azúcar. Universitaria eds. La Habana. Cuba. 785 pp. [In Spanish].

33. INICA. (1987). Normas y procedimientos del mejoramiento genético de la caña de azúcar en Cuba. Instituto Nacional de Investigaciones de la Caña de Azúcar, La Habana, Cuba. 147 pp. [In Spanish].

34. INICA. (2002). Normas y procedimientos del programa de mejoramiento genético de la caña de azúcar en Cuba. Instituto Nacional de Investigaciones de la Caña de Azúcar. Boletín No. 1 Cuba \& Caña-INICA, La Habana, Cuba. 315 pp. [In Spanish].

35. Inman-Bamber N.G., Smith D.M. (2005). Water relations in sugarcane and response to water deficits. Field Crop Res 92, 185-202.

36. Jackson M.B., Colmer T.D. (2005). Response and adaptation by plants to flooding stress. Ann Bot 96, $501-505$.

37. Jackson M.B., Saker L.R., Crisp C.M., Else M.A., Janowiak F. (2003). Ionic and pH signalling from roots to shoots of flooded tomato plants in relation to stomatal closure. Plant Soil 253, 103-113.

38. Jorge H., Morales F., Jorge I,, García H. (2004). Catálogo de nuevas variedades de caña de azúcar. PUBLINICA eds, $1^{\text {st }}$ ed. La Habana. Cuba. 105 pp. [In Spanish].

39. Kouwenberg L., Kürschner W.M., Visscher H. (2004). Changes in stomatal frecuency and size during elongation of Tsuga heterophylla Needles. Ann Bot 94, 561-569.

40. Kouwenberg L., Mcelwain J.C., Kürschner W.M., Wagner F., Beerling D.J., Mayle F.E., Visscher H. (2003). Stomatal frequency adjustment of four conifer species to historical changes in atmospheric $\mathrm{CO}_{2}$. Am $\mathrm{J}$ Bot 90 , 610-619.

41. Kozlowski T.T. (1997). Responses of woody plants to flooding and salinity. Tree Physiology Monograph 1: 129.

42. Kuijper J. (1915). De groie van bladschijf, bladscheede en stengen van het suikerriet. Archief Suikerind. Ned Indië 23, 528-556. [In Dutch]?

43. Lande, R. and Arnold, S.J. (1983) The measurement of selection on correlated characters. Evolution, 37, 12101226.

44. Lake J.A., Woodward F.I., Quick W.P. (2002). Long distance $\mathrm{CO}_{2}$ signalling in plants. J Exp Bot 53, $183-193$.

45. Magalhães P.C., Durães F.O.M., Vitorino F.P.G., Donozeti J.A., Gama E.E.G. (2000). Adaptación del maíz a condiciones de estrés por encharcamiento. Corporación Colombiana de Investigación Agropecuaria (CORPOICA). Ecorregión Caribe. Febrero. s/p. [In Spanish].

46. Magalhães P.C., Durães F.O.M., Andrade C.; DE Oliveira A.C., Souza I.R., Gama E.E.G. (2001). Adaptação do milho a diferentes condições de encharcamento. VII Congresso Brasileiro de Fisiologia Vegetal, Ilhéus, B. A. Anais, p. 8. [In Portughese].

47. Maltby E. (1991). Wetlands their status and role in the biosphere. In: Plant life under oxygen deprivation. ecology, physiology and biochemistry (Jackson M.B., ed). Ed SPB Academic Davies DD, Lambers H, The Hague. pp. 3-21. 
48. Medlyn B.E. (2001). Stomatal conductance of forest species after long-term exposure to elevated $\mathrm{C}_{2}$ concentration: a synthesis. New Phytologist 149, 247-264.

49. Ortega E., Ródes R. (1990). Técnica de medición de la apertura de los estomas. Folleto de Prácticas de Fisiología Vegetal. Pueblo y Educación eds. La Habana. Cuba. 193 pp. [In Spanish].

50. Puijalon S., Bornette G. (2006). Phenotypic plasticity and mechanical stress: biomass partitioning and clonal growth of an aquatic plant species. Am J Bot 93, 1090 - 1099.

51. Pyakurel, A. and Wang, J.R. (2014) Leaf morphological and stomatal variations in paper birch populations along environmental gradients in Canada. American Journal of Plant Sciences, 5, 1508-1520.

52. Raven J. (2002). Selection pressures of stomatal evolution. New Phytologist 153, 371-386.

53. Rice W.R. (1989). Analysing tables of statistical test. Evolution 43, 223-225.

54. Roth-Nebelsick A. (2007). Computer-based studies of diffusion through stomata of different architecture. Ann Bot 100, 23-32.

55. Royer D.L. (2001). Stomatal density and stomatal index as indicators of paleoatmospheric $\mathrm{CO}_{2}$ concentration. Rev Palaeobot Palynol 114, 1-28.

56. Rubin BA. (1984). Curso de fisiología vegetal. Vneshtorgizdat eds., Moscow. Russia. 274 pp. [In Spanish].

57. Schroeder J.I., Kwak J.M., Allen G.J. (2001). Guard cell abscisic acid signalling and engineering drought hardiness in plants. Nature 410, 327-330.

58. Schmalhausen I.I. (1949). Factors of evolution. The theory of stabilizing selection. Chicago: University of Chicago Press. 135 pp.

59. SOIL SURVEY STAFF (2003). Claves para la taxonomía de suelos. Colegio de Postgraduados, Chapingo, México. 306 pp. [In Spanish].

60. Tadeo F.R. (2000). Fisiología de las plantas y el estrés. In: Fundamentos de Fisiología Vegetal. (Azcón-Bieto J., Talón M., eds). Ed McGraw-Hill/-Interamericana de España, Madrid, Spain. pp. 481-498. [In Spanish].

61. Tichá I. (1991). Photosynthetic characteristics during ontogenesis of leaves 7. Stomata density and size. Photosynthetica 16, 375-471.

62. Van Dillewijn C. (1951). Botánica de la caña de azúcar. Revolucionaria eds.. 2nd. ed. Instituto Cubano del Libro. La Habana. Cuba. 460 pp. [In Spanish].

63. Vartapetian B.B., Jackson M.B. (1997). Plant adaptation to anaerobic stress. Ann Bot 79 (Supplement A), 3-20.

64. Wade, M.J. and Kalisz, S.J. (1990) The causes of natural selection. Evolution, 44, 1947-1955.

65. Wagner F., Dilcher D.,Visscher H. (2005). Stomatal frequency responses in hard-swanp vegetation from Florida during a 60 year continuous $\mathrm{CO}_{2}$ increase. Am J Bot 92, 690-695.

66. Wolfe L., Mazer S. (2005). Responses to environmental heterogeneity: fitness consequences of phenotypic stability vs. sensitivity in wild radish (Raphanus sativus: Brassicaceae). Int J Plant Sci 166, 631-640.

67. Zarinkamar F. ( 2007). Stomata observations in dicotyledons. Pakistan J Biol Sci 10, 199-219.

68. Zhang J., Van Toai T., Huynh L., Preiszner J. (2000). Development of flooding - tolerant Arabidopsis thaliana by autoregulated cytokinin production. Mol Breed 6, 135-144. 